九州大学学術情報リポジトリ

Kyushu University Institutional Repository

\title{
Vegetation Morphology and Soil Features Along Unstable Road Slope : A Case Study from Mugling narayanghat Road Section, Central Nepal
}

Devkota, Bimala Devi

Graduate School of Bioresource and Bioenvironmental Sciences, Faculty of Agriculture, Kyushu University

Omura, Hiroshi

Graduate School of Bioresource and Bioenvironmental Sciences, Faculty of Agriculture, Kyushu University

Kubota, Tetsuya

Graduate School of Bioresource and Bioenvironmental Sciences, Faculty of Agriculture, Kyushu University

Paudel Prem P.

Department of soil Conservation and Watershed Management

他

https://doi.org/10.5109/10093

出版情報: 九州大学大学院農学研究院紀要. 53 (1)，pp.201-207，2008-02-28. Faculty of Agriculture, Kyushu University

バージョン :

権利関係 : 


\title{
Vegetation Morphology and Soil Features Along Unstable Road Slope: A Case Study from Mugling Narayanghat Road Section, Central Nepal
}

\author{
Bimala Devi DEVKOTA ${ }^{1}$, Hiroshi OMURA ${ }^{1, *}$, Tetsuya KUBOTA ${ }^{1}$, \\ Prem P. PAUDEL ${ }^{2}$ and HASNAWIR ${ }^{1}$
}

\author{
Laboratory of Forest Conservation, Department of Forest and Forest Products, Graduate School of \\ Bioresource and Bioenvironmnetal Sciences, Faculty of Agriculture \\ Kyushu University, Fukuoka 812-8581 \\ (Received November 9, 2007 and accepted November 30, 2007)
}

\begin{abstract}
In mountain parts of Nepal, road network passes through the geologically young and unstable parts of the landscapes. Every year most of the road sections are blocked by landslide and debris deposition. In this study, one such unstable road called Mugling-Narayanghat road, located at central part of Nepal is selected to understand its erosion state, vegetation morphology, and soil characteristics. For this, four sampling sites are selected by random methods at the accessible sites, representing from different geological units and terrain conditions. This study mainly describes about 1) types of geology distributed along road section, 2) major vegetation types and morphological features of herbaceous plants, and 3) physical characteristics of the soil that are linked with vegetation growth.

The studied road section passes by cut slopes of Mahabharat range of rolling and hilly terrain and characterizes with sharp bends and curved alignment along the bank of the Trishuli River. The area receives average annual rainfall of about $2400 \mathrm{~mm}$. Highly weathered phyllite, metasandstone, quartzite, are major geological types along the road section. For an individual species, we examined mean shoot height, maximum rooting depth, number of root tendrils contained, maximum diameter of a single root, root:shoot ratio, and pull out resistive force. For the sake of evaluation of plant species, they are categorized into different groups based on their morphological properties. We classified the plants based on mean shoot height $(\geq 50 \mathrm{~cm})$, maximum rooting depth $(\geq 20 \mathrm{~cm})$, number of root tendrils ( $\geq 30$ no.), maximum diameter of a root $(\geq 7 \mathrm{~mm})$, root shoot ratio $(\geq 0.5$, dry), and pull out resistive force $(\geq 100 \mathrm{~N})$. It was revealed that the species like Eulaliopsis binata, Elaeagnus parvifolia, Saccharum spontaneum, Colebrookea oppositifolia, were characterized with relatively higher number of roots, root longetivity and greater resistance to pulling force. These species are easy to grow and are available on varying site conditions.
\end{abstract}

\section{INTRODUCTION}

Road networks are regarded as being necessary to promote development and are given higher national priority. In Mid Hill region, road networks are expanding through cutting the unstable hilly slopes. An estimated average of $500 \mathrm{~m}^{3} / \mathrm{km} / \mathrm{yr}$ of debris, and up to $2000 \mathrm{~m}^{3} / \mathrm{km}$ sediment are generated, which is 10 times greater than those expected under natural conditions (ODA report, 1997). In rainy season, many shallow landslides occur along the roadside slope and vehicle, traffic movement is disturbed. Mitigation efforts by the government are becoming major concern with greater financial burden. The Mugling-Narayanghat road is one of such example. In this area, the road passes by cut slopes of Mahabharat range of rolling and hilly terrain and characterizes with sharp bends and curved alignment. The road section is $36 \mathrm{~km}$ long and is one of the important routes in national network to join capital city Kathmandu from the east west parts of the country. It is aligned along the bank of the Trishuli River. The topographic and geological settings are favoring for recurrent erosion activities every

1 Laboratory of Forest Conservation, Department of Forest and Forest Product sciences, Graduate School of Bioresource and Bioenvironmnetal Sciences, Faculty of Agriculture, Kyushu University, Fukuoka 812-8581

2 Department of Soil Conservation and Watershed Management, Kathmandu, Nepal

* Corresponding author (Email: homura@agr.kyushu-u.ac.jp) year. For instance, intensive rainfall of $446 \mathrm{~mm}$ in 24 hours on July 2003 triggered 213 shallow landslides, as shown in Fig. 1. This has caused washed away of bridges and retaining walls, and blocked traffic for couple of days (Joshi, 2006). Sometimes road-blocked problems create food scarcity in Kathmandu. Hence, considerations on its measures for slope stabilization are recognized as an important matter.

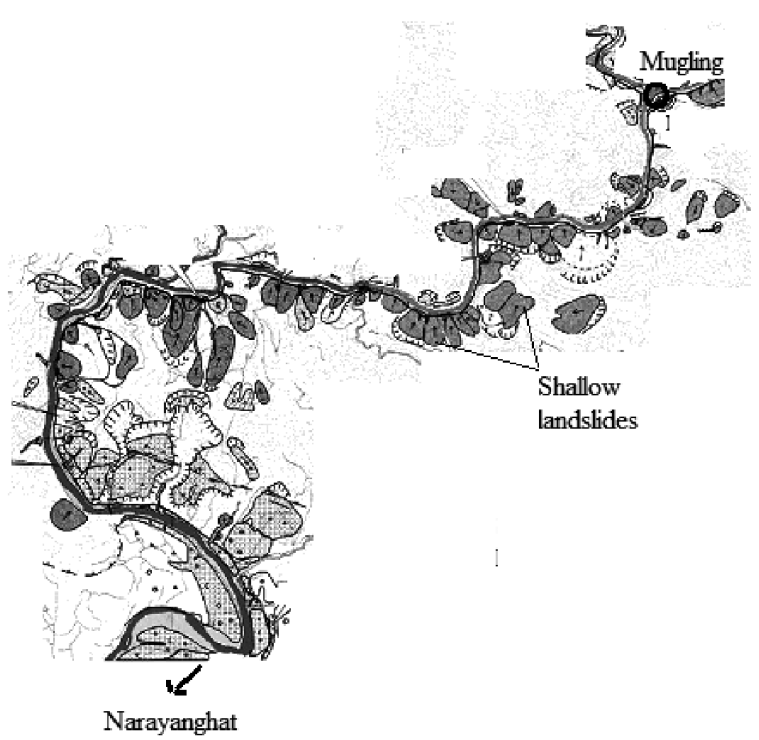

Fig. 1. Landslides distribution along Mugling-Narayanghat road. (after Hasegawa et al., 2006) 
Owing to its economic importance and unstable terrain conditions, efforts on slope stabilization measures are becoming essential. In this context, the government of Nepal is implementing project called "MuglingNarayanghat Road Rehabilitation Project". The hardware concrete structures and bioengineering measures are constructed to reduce the erosion problems. For effective management of road slope, both vegetation and mechanical/structural components are important. Vegetation provides additional slope stability through its mechanical and hydrological functions. Examination of vegetation along roadside slope might provide the basis to mitigate erosion problems.

In this paper, a study is attempted to understand site-specific conditions related with soil and vegetation distributed along the road. This kind of study might provide basis for implementation of bioengineering solution. The specific objectives of this study are to investigate;

1) soil, geology, and vegetation types distributed along the road side slope,

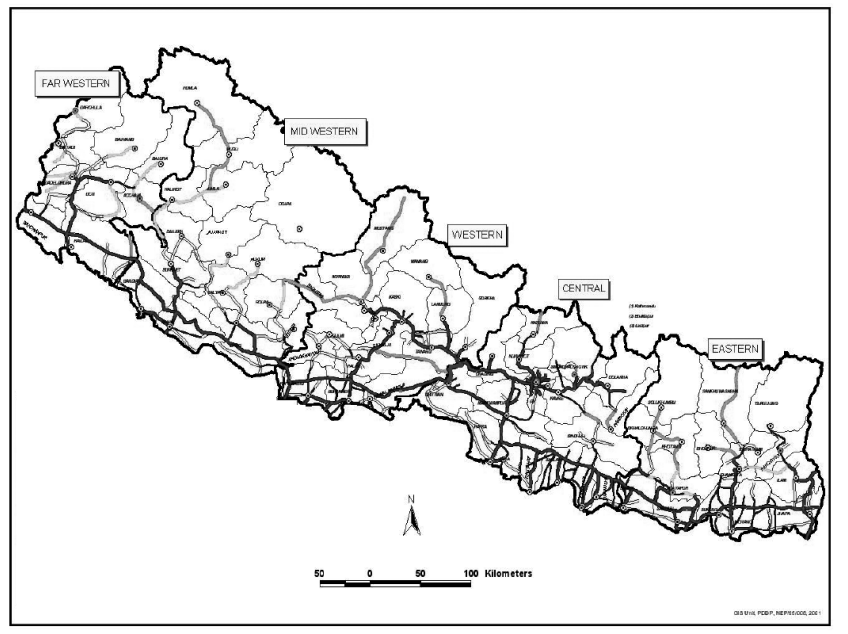

2) morphological features of plant community grown.

\section{STUDY AREA}

The Mugling-Narayanghat road is located at central Nepal. The road connects not only Mugling and Narayanghat towns but also eastern and western part of country as shown in Fig. 2a. The road passes through plain, rolling and hilly terrain with curved alignment.

The road passes through plain rolling terrain with curved alignment which is shown in fig. $2 \mathrm{~b}$ and $2 \mathrm{c}$. The area receives average annual rainfall of about $2400 \mathrm{~mm}$ and the area belongs to subtropical zone. The local farmers are practicing agriculture farming on steep slopes parts of road side slopes. The forest condition is in degraded conditions with shrubs and bush as dominant communities. The tree species are sparse. Every year many landslides, debris flows are occurring along the road slopes in vegetative, as well as in cultivated slopes, as shown in Fig. 3.

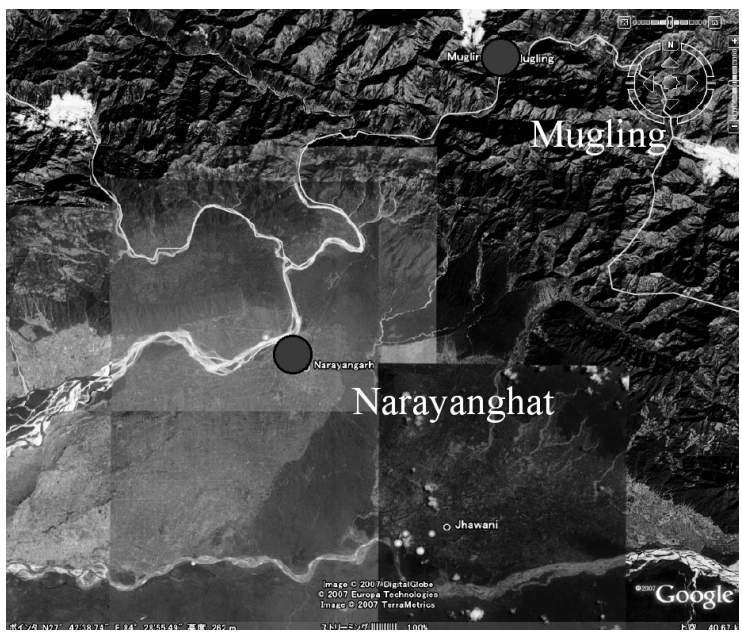

$\mathrm{b}$

a

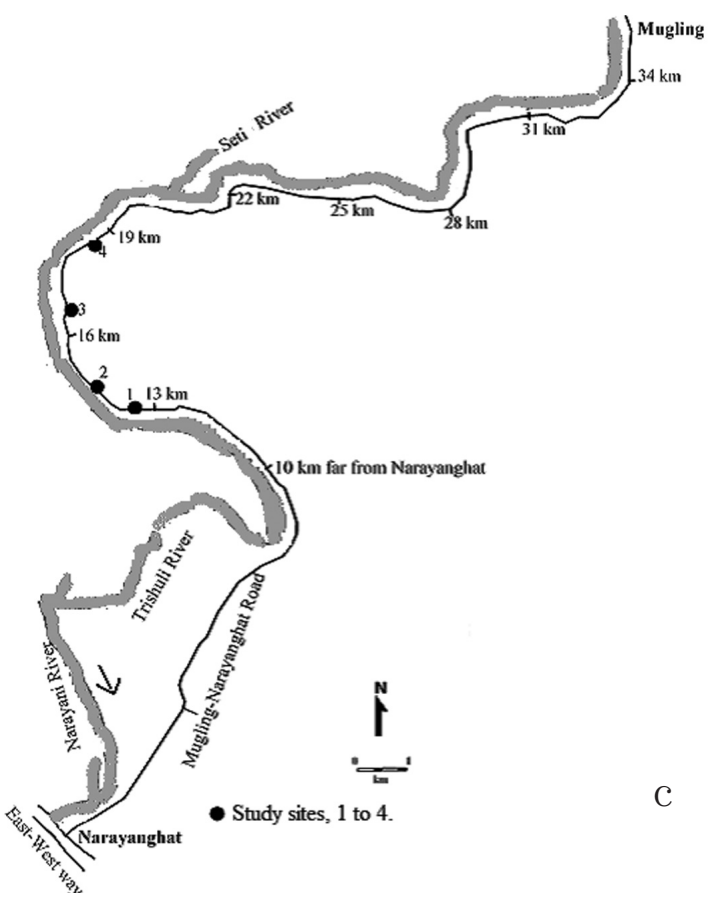

Fig. 2. Location of study area and its alignment view from Mugling to Narayanghat.
a) view of national road networks
b) satellite image of study area
c) view of road alignment 


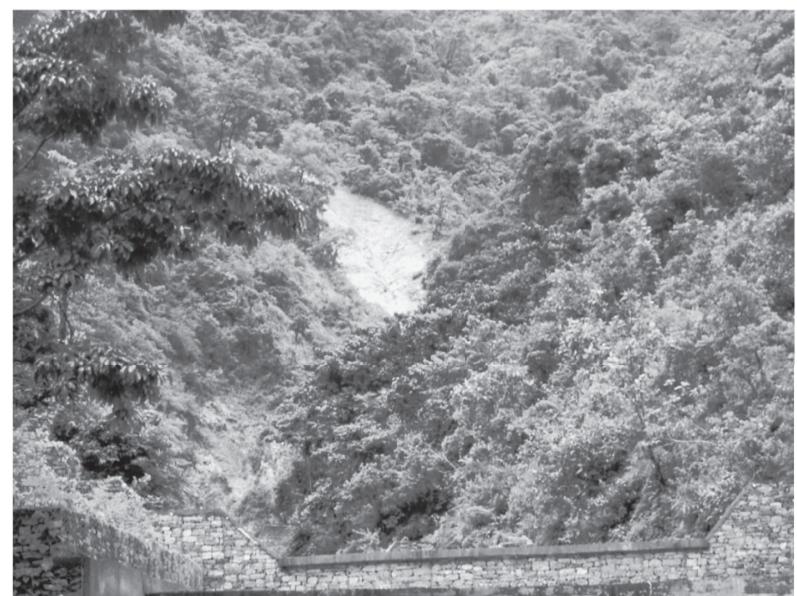

slide on forested slope

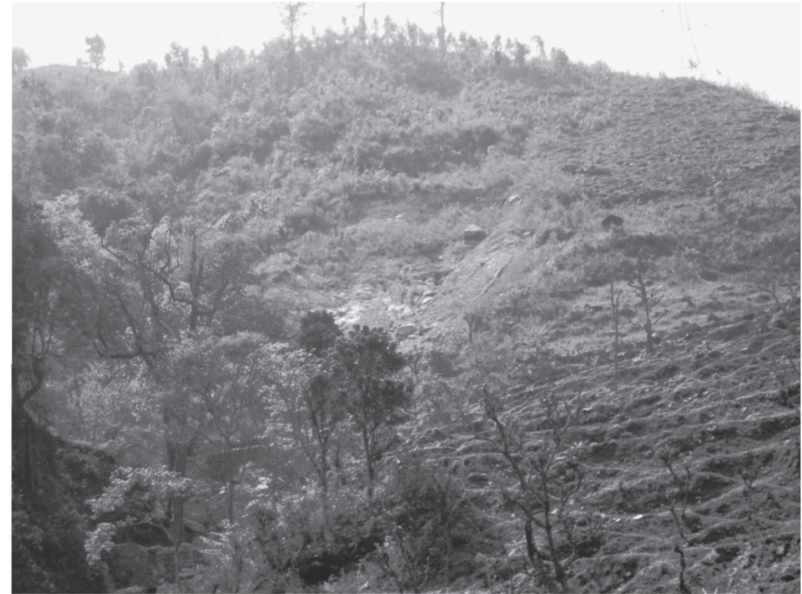

slide near cultivated slope

Fig. 3. Occurrence of landslides along the road side slopes.

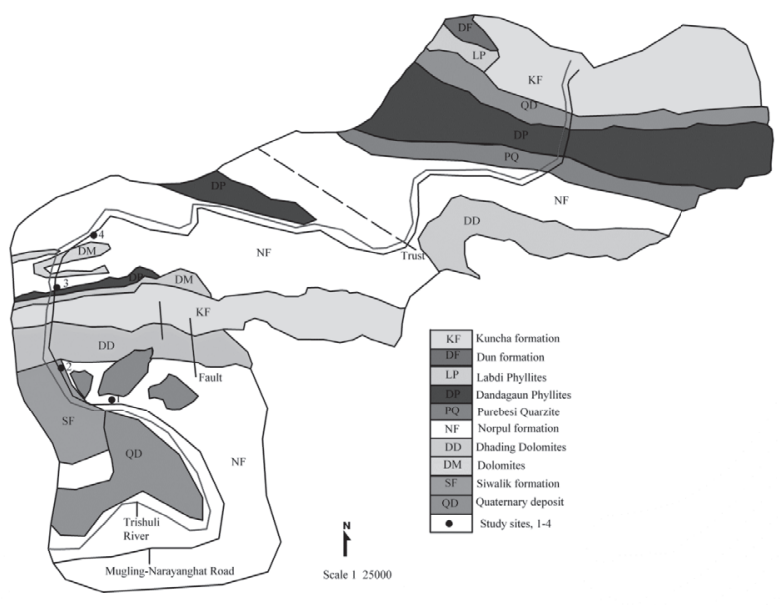

Fig. 4. Geological types at sampling locations distributed along Mugling-Narayanghat road.

\section{Geologogical features}

The road passes by cut slopes of Mahabharat range of rolling and hilly terrain. According to Joshi, (2006); the geological units along the road sections are of following types and the distribution pattern is shown in Fig. 4.

- Kuncha formation of highly weathered phyllite and metasandstone,

- Fagfog quartzite, grey feeble dandagaon phyllites.

- Norpul formation, which extensively distributed and comprises purebesi quartzite,and slates,

- Grey dhading dolomite.

- Cleaved carbonaceous benighat slates and

- Dun valley gravel.

\section{STUDY METHODS}

The vegetation, geology, and soil features were studied by selecting sampling sites. Four sampling sites, as shown in Figs. 2 and 4, were selected by random methods at the accessible sites, which were taken representing from different geological units and terrain conditions. For understanding of geological conditions, the geological map prepared by the Department of Water Induced
Disaster Prevention was taken as a reference. The partial glimpse of each sampling locations is shown in Fig. 5.

The soil samples were taken from each sampling sites and soil features like permeability, density and mineral contents (NPK) were tested at the laboratory. The vegetative features were analyzed in the field on 2006 August and 2007 March. The plant morphological features such as shoot height, roots numbers, root diameter, and numbers of root tendrils of an individual plant species were examined by extracting from the ground. The plants were extracted by following two ways, as shown in Fig. 6;

1) using Digital Push Pull Gauge. This was applied where it was possible to extract plant without damage to the roots. Sometimes extraction work of plants was difficult because of its limited capacity (maximum of $1000 \mathrm{~N}$ ),

2) by digging a circular pit to observe root morphology at the impossible case of digital gauge. In this case the data on Pulling Resistance Force (PRF) of an individual plant are not measured.

\section{RESULTS}

\section{Geology and soil}

The geological characteristics, and physical properties of soil like density, organic matter contents, soil nutrients, and $\mathrm{pH}$, for sampled sites were examined in detail and the results obtained are listed in Table1 and Table 2, respectively. Geologically, four types of units were identified. According to geology erupted out, site 1,3 , and 4 comprises Norpul formation that is extensively composed of purebesi, quartzite, and slates. Only site 2 is belonged to Siwalik formation. Here the rock type controls soil physical conditions, because the weathering of slate and dolomites supply fine materials to clay that can keep water parts clearly in dry season. As a result, texture and mineral contents in sites 1 and 2 are similar. Also those in site 3 and site 4 are similar. In site 1 and 2, the fraction of sand is remarkably higher compared to site 3 and 4 . However; in all sites, fraction of sand is 


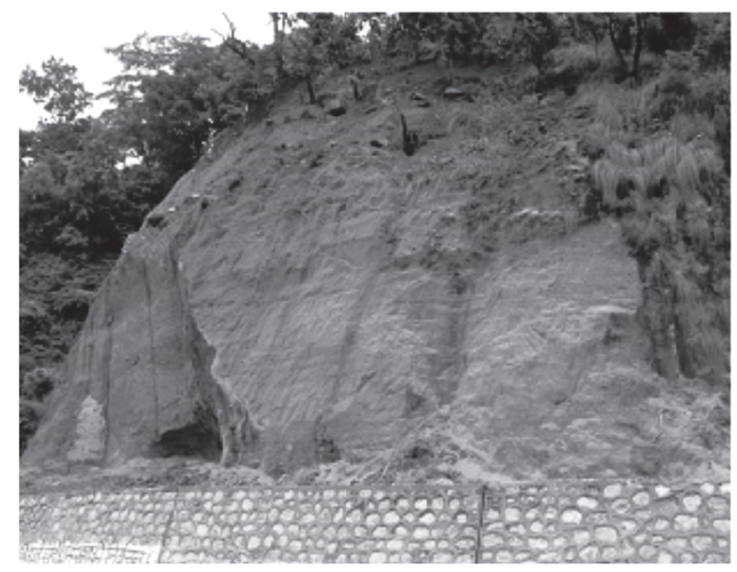

sampling site 1

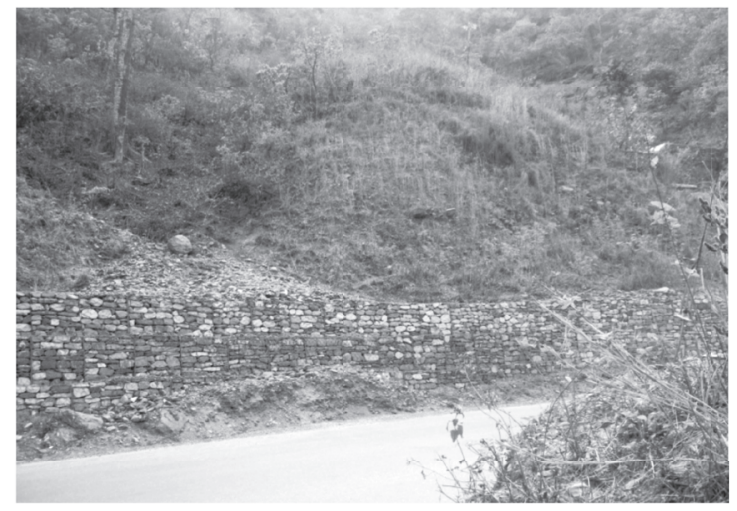

sampling site 3

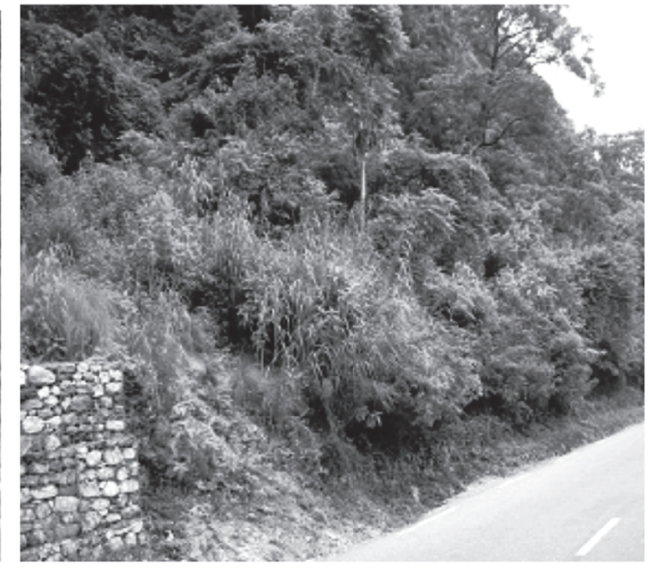

sampling site 2

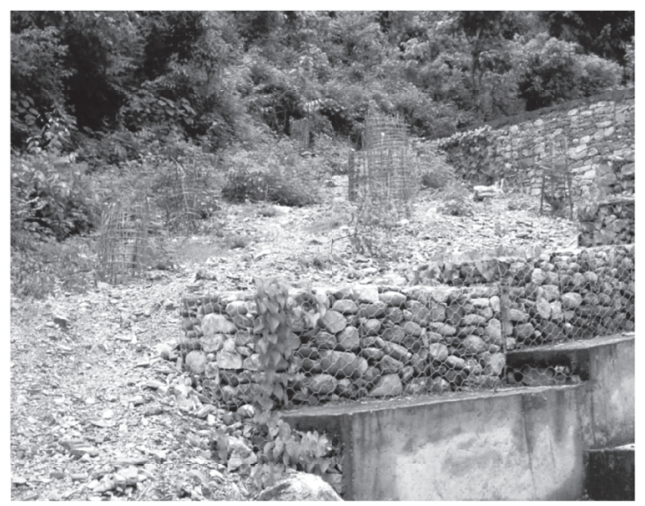

sampling site 4

Fig. 5. Partial view of sampling point locations.

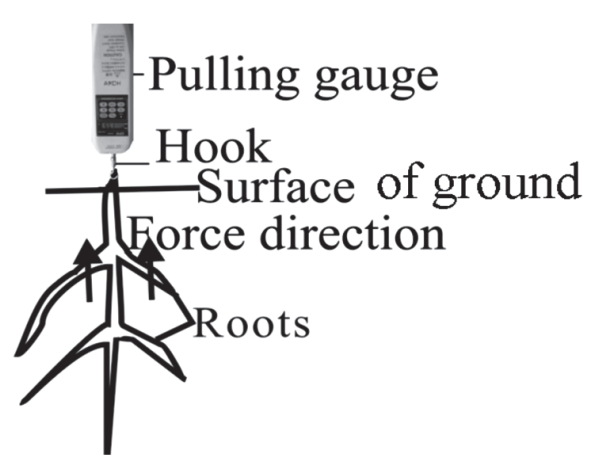

a

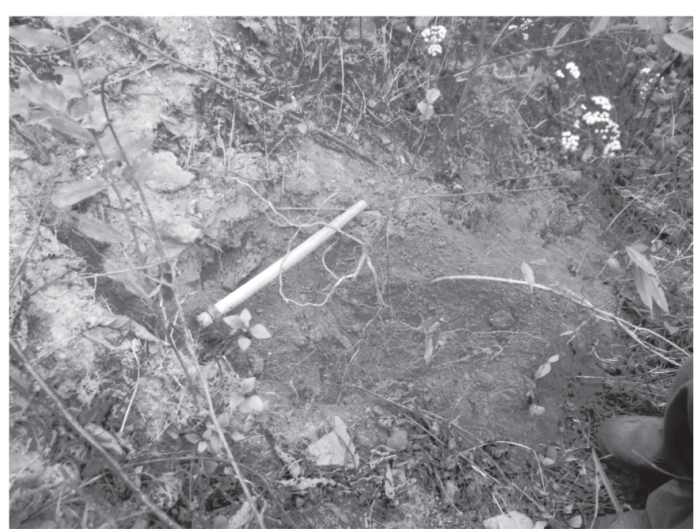

$\mathrm{b}$

Fig. 6. Methods applied for extraction of plants from ground surface.

a) shows pulling a plant using digital gauge

b) plant extracting by digging a circular pit

Table 1. Geological conditions in four sampling locations

\begin{tabular}{ccl}
\hline $\begin{array}{c}\text { Sampled } \\
\text { site }\end{array}$ & $\begin{array}{c}\text { Distance from } \\
\text { Narayanghat }(\mathrm{km})\end{array}$ & Geological type \\
\hline 1 & 14 & $\begin{array}{l}\text { Norpul formation, which extensively } \\
\text { comprises } \\
\text { Purebesi quartzite, slates. }\end{array}$ \\
2 & & $\begin{array}{l}\text { Siwalik formation, dolomites } \\
\text { Dandagaun Phyllite/Norpul formation } \\
4\end{array}$ \\
\hline
\end{tabular}

dominant compared to silt, and clay fraction, whose fraction ranges from $43.5 \%$ to $71.7 \%$. The color of the soil ranges from dull yellow orange to light gray. In most of the sampled sites, the soil is almost neutral in nature, ranging $\mathrm{pH}$ from 6.4 to 7.5 .

Early morphology of colonized plants

In any location, edaphic factors like soil depths, soil quality and other site-specific characters like moisture availability control the availability of plant species and their morphological features. For the same species too, 
Table 2. Soil properties observed at four different sampled locations

\begin{tabular}{|c|c|c|c|c|c|c|c|c|c|c|c|c|}
\hline \multirow[t]{2}{*}{ S. no } & \multirow{2}{*}{$\begin{array}{l}\text { Den. } \\
(\mathrm{gm} / \\
\left.\mathrm{cm}^{3}\right)\end{array}$} & \multirow[t]{2}{*}{$\begin{array}{c}\mathrm{D} \\
(\mathrm{m})\end{array}$} & \multirow[t]{2}{*}{$\begin{array}{c}\mathrm{H} \\
(\mathrm{mm})\end{array}$} & \multicolumn{3}{|c|}{$\begin{array}{l}\text { Texture } \\
(\%)\end{array}$} & \multicolumn{5}{|c|}{$\begin{array}{c}\text { Mineral content } \\
(\%)\end{array}$} & \multirow[t]{2}{*}{$\begin{array}{l}\text { Color } \\
\text { (10YR) }\end{array}$} \\
\hline & & & & Sand & Silt & Clay & $\mathrm{N}$ & $\mathrm{P}$ & $\mathrm{K}$ & $\mathrm{pH}$ & $\mathrm{OM}$ & \\
\hline 1 & 1.38 & 0.50 & 11 & 45.5 & 40.5 & 14.0 & 0.085 & 25 & 27 & 7.5 & 1.25 & $\begin{array}{l}7 / 4 \quad \text { dull } \\
\text { yellow orange }\end{array}$ \\
\hline 2 & 1.41 & 0.45 & 13 & 43.5 & 40.5 & 16.0 & 0.730 & 23 & 30 & 6.8 & 1.21 & $\begin{array}{l}6 / 2 \text { grayish } \\
\text { yel low brown }\end{array}$ \\
\hline 3 & 1.41 & 0.25 & 14 & 71.1 & 22.0 & 5.5 & 0.097 & 29 & 26 & 6.5 & 1.43 & 7/1 light gray \\
\hline 4 & 1.35 & 0.40 & 12 & 70.5 & 20 & 9.0 & 0.095 & 28 & 25 & 6.4 & 1.35 & 7/1 light gray \\
\hline
\end{tabular}

M-N: Mugling-Narayanghat, Den: density of soil at natural condition, H: Hardness of soil, D: soil depth, N: Nitrogen, P: Potassium, K: Phosphorus, PH: potential of hydrogen ion, OM: organic matter content.

Table 3. Classification of an individual species effective to slope stability based on morphological characteristics

\begin{tabular}{|c|c|c|c|c|c|}
\hline $\begin{array}{c}\mathrm{MH} \\
(\geq 50 \mathrm{~cm})\end{array}$ & $\begin{array}{c}R_{l} \\
(\geq 20 \mathrm{~cm})\end{array}$ & $\begin{array}{c}\mathrm{T}_{\mathrm{r}} \\
(\geq 30 \text { no.) }\end{array}$ & $\begin{array}{l}\text { Dmax. } \\
(\geq 7 \mathrm{~mm})\end{array}$ & $\begin{array}{l}\text { R:S (dry) } \\
\text { ( } \geq 0.5 \text {, dry) }\end{array}$ & $\begin{array}{c}\text { PS } \\
(\geq 100 \mathrm{~N})\end{array}$ \\
\hline Coix lacryma* & C. lacryma* & C. lacryma* & E. parvifolia & C. lacryma* & E. binata \\
\hline Eulaliopsis binata & E. binata & E. binata & M.melabathricum & E. binata & S.spontaneum \\
\hline Saccharum spontaneum & E. parvifolia & S. spontaneum & E. adenophorum & E. parvifolia & E. parvifolia \\
\hline Elaeagnus parvifolia & M. melabathricum & P. paniceum & C. oppositifolia & P. paniceum & C.oppositifolia \\
\hline Pogonatherum paniceum & Colebrookea oppositifolia & M.melabathricum & W. fruticosa & M. melabathricum & P. vitata \\
\hline Melastoma melabathricum & Woodfordia fruticosa & C. oppositifolia & C. gigantia & C. oppositifolia & B. minor \\
\hline Eupatorium adenophorum & Holarrhena pubescens & W. fruticosa & H. pubescens & $W$. fruticosa & \\
\hline Pteris vitata & Dicranopteris linearis* & P. vitata & Butea minor & P. vitata & \\
\hline Pennisetum purpureum & Buddleja asiatica* & C. lacryma & B. asiatica & P. purpureum & \\
\hline Calotropis gigantia & C. lacryma & N. arbo-tristis & N. arbo-tristis & C. gigantia & \\
\hline Eurya acuminata* & N. arbo-tristis & & & B. minor & \\
\hline
\end{tabular}

MH: Mean shoot height; $\mathrm{R}_{\mathrm{l}}$ : maximum length of a root, $\mathrm{T}_{\mathrm{r}}$ : total numbers of roots, Dmax: maximum diameter of a root, R:S : root shoot ratio in dry condition, PS : pulling strength (Newton) or pullout resistive force

* Plants extracted by digging a circular pit.

differences in site qualities can bring variations on morphological features. In this context, it is hard to obtain and generalize the plant morphological features. However, in this study we attempted to obtain some morphological features for an individual species, based on sampled examinations. For an individual species, we examined mean shoot height, maximum rooting depth, number of root tendrils contained, maximum diameter of a single root, root:shoot ratio, and pull out resistive force. For the sake of evaluation of plant species, they are categorized into different groups based on their morphological properties. We classified the plant species based on having mean shoot height $(\geq 50 \mathrm{~cm})$, maximum rooting depth $(\geq 20 \mathrm{~cm})$, number of root tendrils ( $\geq 30$ no.), maximum diameter of a root ( $\geq 7 \mathrm{~mm}$ ), root shoot ratio ( $\geq 0.5$, dry condition), and pull out resistive force $(\geq 100 \mathrm{~N})$. The individual plants belonging to different groups are summarized in Table 3. Based on field observation it was revealed that among the vegetation distributed along the road slopes few were tree species, and mainly dominated by shrubs, and grasses. From the Table, it can be revealed that the species like Eulaliopsis binata, Elaeagnus parvifolia, Saccharum spontaneum, Colebrookea oppositifolia, are characterized with relatively higher number of roots, root longetivity and greater resistance to pulling force. These species are easy to grow and are available on varying site conditions. Based on these advantages these species might be considered more effective for bioengineering solution. The morphological views of these plants are shown in Fig. 7

\section{DISCUSSION}

In the study area, we can easily observe the erosional phenomenon like landsliding, and gully formation along the both sides of road section. There have been several occasions of highway closure for several days due to large-scale failures of the roadside slopes. The area is considered to be more prone to erosion, which might be attributed to;

1) presence of weak and geologically unconsolidated rock materials such as phyllite. This facilitate for easy slip due to action of rain,

2) steep terrain conditions and road is passing through cutting unstable slopes,

3) local farmers are practicing unsuitable cultivation along upper and below slope surface. For instance, they are cultivating maize, banana by making terrace. They frequently disturb the soil compactness.

4) forest is deteriorating and almost large sized tree species are already felled and only bush species are remaining along roadsides. Further, farmers are also practicing shifting cultivation. All of these conditions might be favorable for landsliding.

5) road is aligned along the bank of the Trishuli River. So 


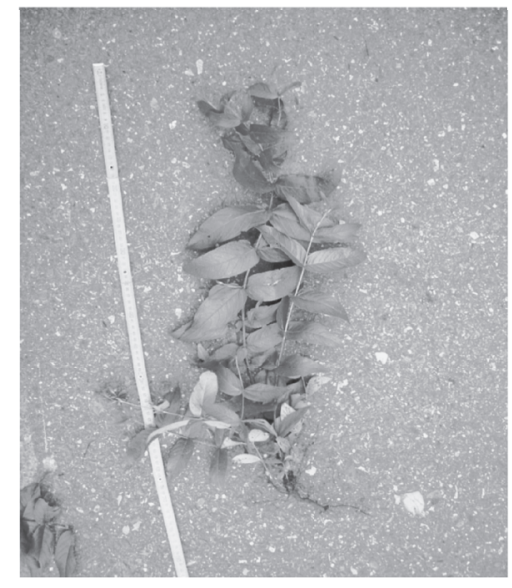

Woodfordia fruticosa

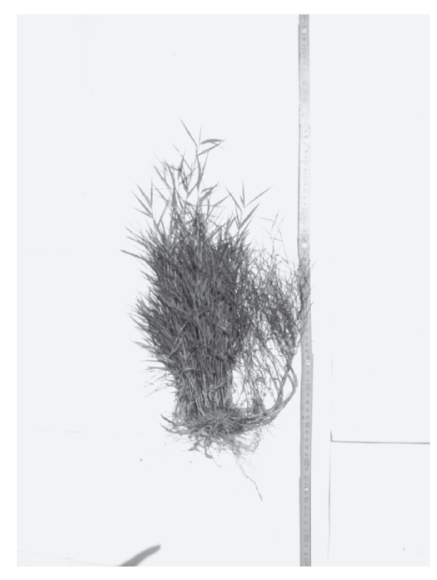

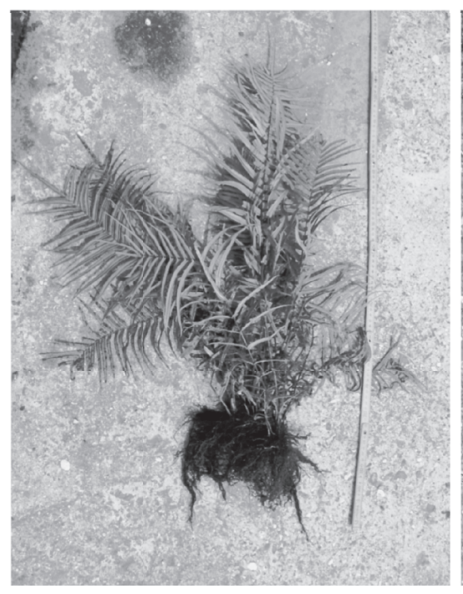

Pteris vitata
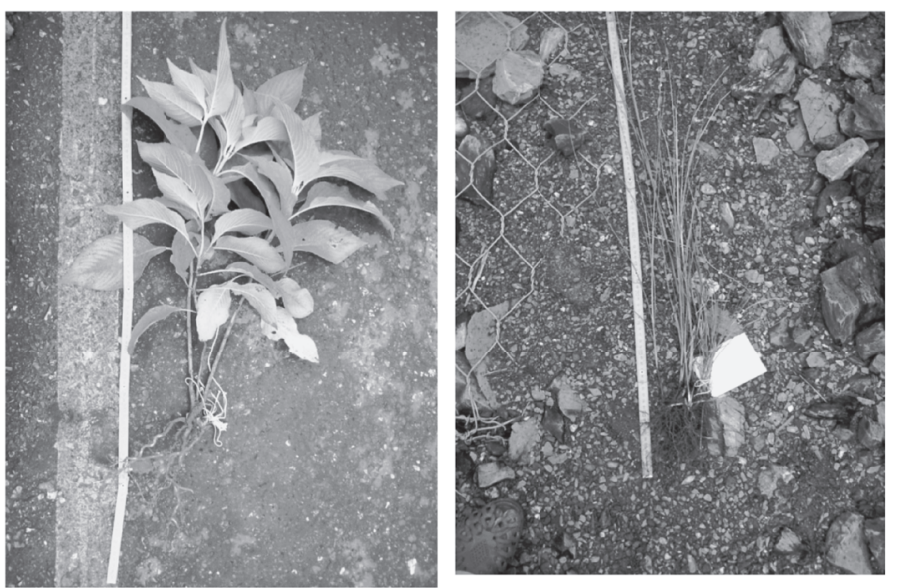

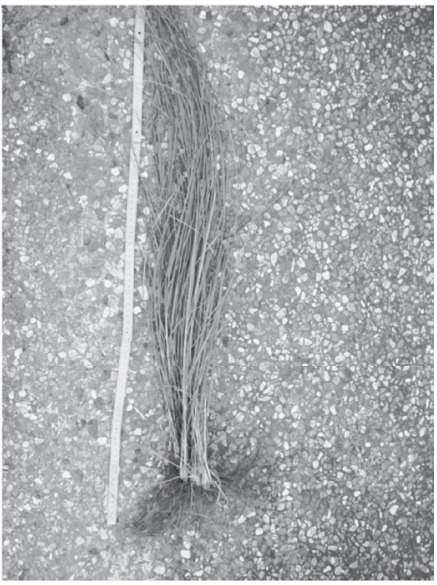

Eulaliopsis binata

Saccharum spontaneum

Pogonatherum paniceum Colebrookea oppositifolia

Fig. 7. Morphological views of some plants after extraction.

the stream bank is continuously scouring by flow water action might disturb natural balance of slopes.

In one side, the road is prone to different kinds of erosion while; in another side the road has very socioeconomic importance for the nation. Thus the erosion mitigation measures are becoming essential. The hardware structures alone are not suitable because of higher cost and the technical problems with steep terrain nature. The combinations of hardware and bioengineering measures are considered to be more effective. Characters of site specific conditions like geology, soil, and vegetation features help for the implementation of bioengineering solution. Establishment of only vegetative structures might not be effective to control the erosion in short time duration, instead combination of structural and vegetative measures are suggested for effective road slope management.

\section{CONCLUSION}

In this study site-specific characteristics like soil, geology, vegetation types and their morphological fea- tures distributed along the different sections of road are examined. This kind of study might help to provide the basis to understand its terrain nature, and vegetation features needed to carry out bio engineering solution. The vegetation grown along the roadside slopes have provided important role for reducing surface erosion. Most of the species were herbaceous so their root longetivity were shallow with weak connection with rock soil mass. Root system sizes had differed among growth forms and increased with above-ground size: annuals $<$ perennial forbs $=$ grasses $<$ semi-shrubs $<$ shrubs $<$ trees. The presence of herbs, shrubs and perennial plants with combined root system has provided positive support for ground surface protection. In this study, presence of larger tree species were noticed at few quantity and most of the vegetation were of herbaceous. As a result roots system might have weak influence to bind the soil-rock mass. In this context, more tree species are needed to grow either artificially or naturally. If the vegetative measures are properly installed and managed the problems can be reduce significantly. 


\section{REFERENCES}

Joshi, S. P. 2006 A sustainable way of controlling debris flows and landslides along Mugling-Narayanghat road. Department of Water Induced Disaster Prevention Bulletin, pp. 29-32

Hasegawa, S., Dahal, R. K., Bhandary N. P., Yatabe R., Yamanaka, M. 2006 Highways of Central Nepal and Large-Scale Landslides. International Symposium on Geo disasters, Infrastructure management and protection of world heritage sites, Kathmandu, Nepal, pp. 77-85

ODA, 1997 Principles of low cost road engineering in mountainous regions. Overseas Road Note, Transport research laboratory, Crowthorne, Berkshire UK, 16: 116-145

Shrestha, M. B. and Yamadera, Y. 2001 Vegetation analysis in steep cut slope areas of Siwalik, Nepal. Journal of the Japanese society of re-vegetation technology, 27(2): $416-429$ 